\title{
The Economic Impact of DOE/AL/64506--963 Los Alamos National Laboratory on North-Central New Mexico and the State of New Mexico Fiscal Year 1995
}

by

Robert R. Lansford, Professor

Department of Agricultural Economics and Agricultural Business

New Mexico Agricultural Experiment Station

New Mexico State University

Las Cruces, New Mexico

and

Larry D. Adcock, Economist

Lucille M. Gentry, Program Analyst

Institutional Management Team

Science and Technology Transfer Division

Office of Energy, Science and Technology

Albuquerque Operations Ofice

U.S. Department of Energy

Albuquerque, New Mexico

and

Shaul Ben-David

Professor, Emeritus

Department of Economics

University of New Mexico

Albuquerque, New Mexico

CHe

August 1996 


\section{DISCLATMER}

Portions of this document may be illegible in electronic image products. Images are produced from the best avallable original document. 


\section{PREFACE}

The Albuquerque Operations Office (AL) of the U.S. Department of Energy (DOE) is charged with managing laboratories, production plants, and energy programs in several loctations throughout the United States, including New Mexico. Due to the significance of DOE activities in New Mexico, selected economic impact studies have been completed annually since the early 1980s. The types of activities that DOE/AL oversees are, for the most part, an outgrowth of atomic research that started in New Mexico in the 1940s. In New Mexico, activity that was once confined to "the Hill" (Los Alanos National Laboratory), northwest of Santa Fe, has become two nalional laboratories, a biomedical and environmental research institute; a national waste repository, a national remedial action project, and several energy research and conservation programs.

The cconomic impact on New Mexico has grown over the years to a point where these activities provide lens of thousands of jobs and contribute billions of dollars to the state's economy. Therefore, it is appropriate that a report be provided periodically to the citizens of New Mexico describing the impact of DOE on the state. This report details activities for federal Fiscal Year 1995.

\section{DISCLAIMER}

This repact was prepared as an account of watk sponsored by an agency of the United Staics Gowemmitn. Neither the United States Gorementent nor any agency theroof, nor any of their

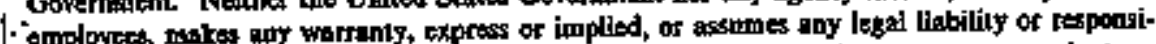
bility for the accorscy, completeness, or usefulness of any information, apparates, produch, or process disclosed, or tepresents that its use woukd not infinge prirgtely onred rights. Reference hereit to any specific commercial product, process, of service by trode aume, tradematk, manufacturte, or otherwite does not aecessarily constiknte or imply tis entiorsoment, recom-

$f$ mepdation, of lavoring by the United Stetes Govtroment of any asency thereof. The views and opintous of astbors expreseed berein do not abcessarily state or refect those of the Unifed Scated Giverimitim of ang sigency thereof. - 


\section{ACKNOWLEDGMENTS}

As is the case with studies of this type, many more people contributs to the effart than just the listed authors. The detailed information needed for the economic modeling and expenditure analysis could not bave been obtained wilhout the support of several individuats. Moreover, there are some who contribute but their contributions are not always acknowiedged-to those individuals, we apologize.

The employment data by economic sector used in the regional model was obtained from the New Mexico Department of Labor (NMSOL). Larry Blackwell, Chief, Economic Research and Analysis Bureau, NMDOL, made certain we obtained the detailed, but unpublished, data needed for our research. Steve Pazand, Unit Supervisor, Actuarial Research, NMDOL also assisted the study team in obtaining the appropriate data. Iriportantly, this state govermment department has cooperated fully with our research efforts for several years and should be commended for their continaing efforts to participate in regional economic studies.

Janet M, Smith, Staff Accountant, Albuquerque Financtal Service Center, Departunent of Energy (DOE) Albuquerque Operations Office, contacted all the DOE agencies to obtain expenditure information for this study. We thank the LANL budget officials who provided burget and expenditure data in a timely fashion, specifically Newby Ellington and Randy Hodges. Also, we thank John Mott, L.ANL, who provided summarized achievements information.

Tomrnie Nielsen, Reports Layout Typist, Department of Agricultural Economics and Agricultural Business, New Mexico State University, typed several drafts, the final report, and assured that study information was transmitted among the authors. 


\section{TABLE OF CONTENTS}

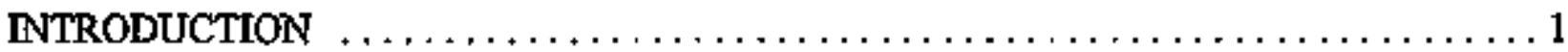

PROFILE OF LOS ALAMOS NATIONAL LABORATORY $\ldots \ldots \ldots \ldots \ldots \ldots \ldots \ldots \ldots$

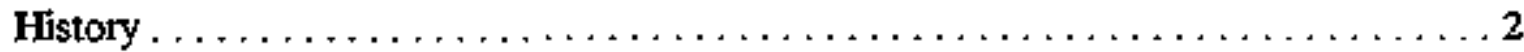

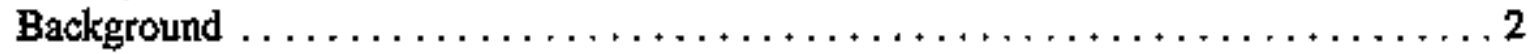

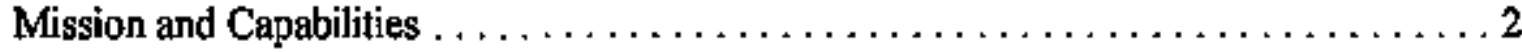

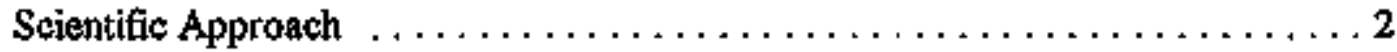

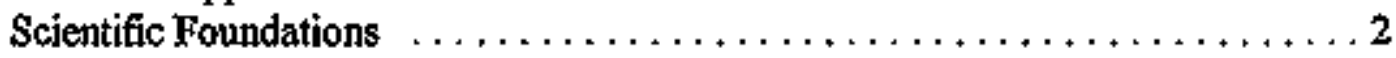

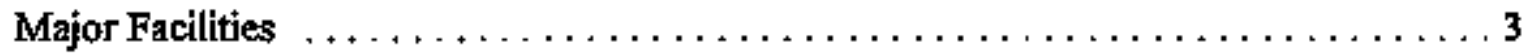

Achievements $\ldots \ldots \ldots \ldots \ldots \ldots \ldots \ldots+\ldots \ldots \ldots \ldots+\ldots \ldots \ldots+\ldots \ldots \ldots+\ldots \ldots \ldots, 3$

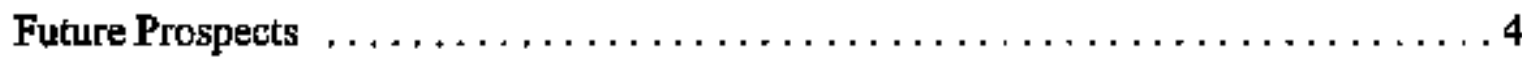

ECONOMIC IMPACTS OF LANL ON NORTH-CENTRAL NEW MEXICO, FY $1994 \ldots \ldots 4$

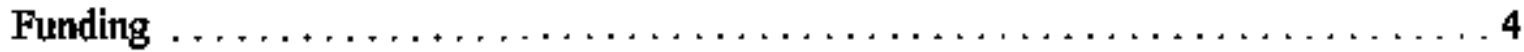

LANL Expenditure Patterns $\ldots \ldots \ldots \ldots \ldots \ldots \ldots \ldots \ldots \ldots \ldots \ldots \ldots \ldots \ldots \ldots$

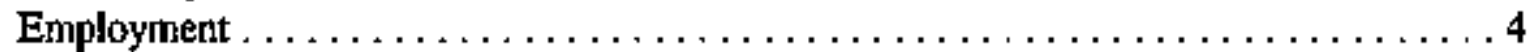

Measuring the LANL Economic Impact on Notth-Central New Mexico $\ldots \ldots \ldots \ldots .4$

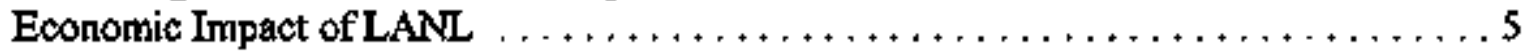

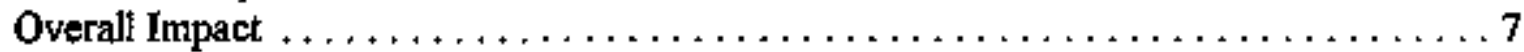

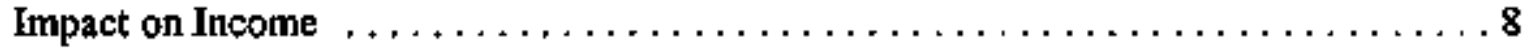

Impact on Employment $\ldots \ldots \ldots \ldots \ldots \ldots \ldots \ldots \ldots \ldots \ldots \ldots \ldots \ldots$

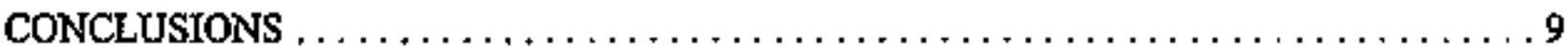

ECONOMIC IMPACTS OF LANL ON THE STATE OF NEW MEXICO, FY $1994 \ldots \ldots \ldots$. . 9

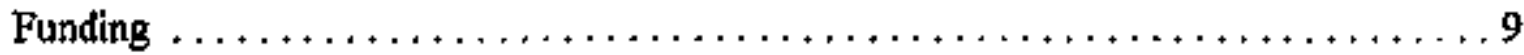

LANL Expenditure Patterns $\ldots \ldots \ldots \ldots \ldots \ldots \ldots \ldots \ldots \ldots \ldots \ldots$

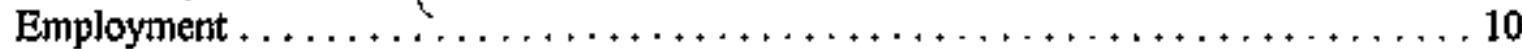

Measuring LANL's Economic Impact on New Mexico $\ldots \ldots \ldots \ldots \ldots \ldots \ldots \ldots 11$

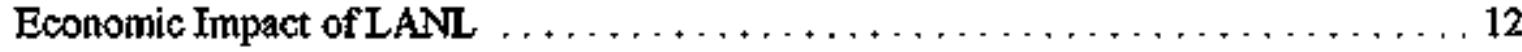

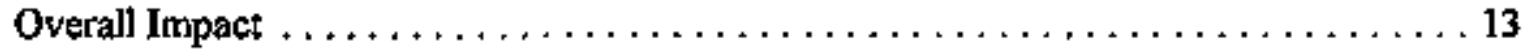

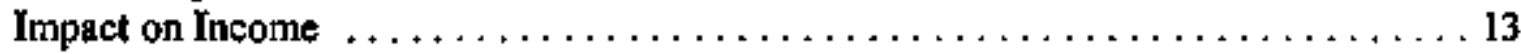

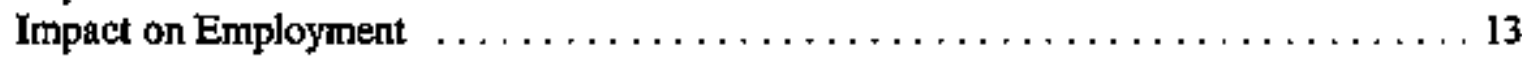

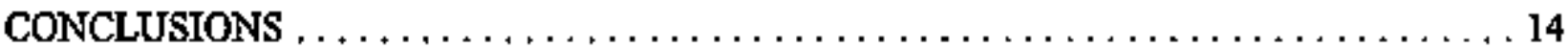

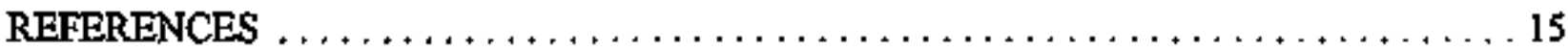

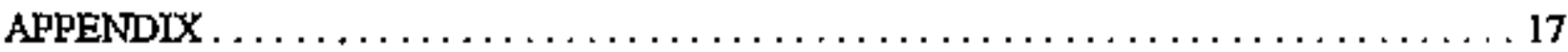




\section{LIST OF TABLES}

Table 1. LANL Expenditures (in Dollars) in North-Central New Mexico by Sector and Total Operating Budget, FY $1995 \ldots \ldots \ldots \ldots \ldots$.

Table 2. Los Alamos National Laboratory Expenditures in North-Central New Mexico by Major Sector, FY $1995 . \ldots \ldots \ldots \ldots \ldots \ldots 6$

Table 3. LANL Funding In-Region Expenditures and Employment by Major in North-Central New Mexico, FY $1995 . \ldots \ldots \ldots \ldots \ldots 6$

Table 4. Los Alamos National Laboratory Regional Influence on North-Central New Mexico's Economy, FY 1995. . . . . . . . . \& 8

Table 5. LANL Expenditures (in Dollars) in New Mexico by Sector and Total Operating Budget, FY 1995. . . . . . . . . . . . . . . 10

Table 6. Los Alamos National Laboratory Expenditures in New Mexico by Major Sector, FY $1995 . \ldots \ldots \ldots \ldots \ldots \ldots \ldots \ldots \ldots \ldots 11$

Table 7. LANL Funding, Instate Expenditures and Employment by Major Entity in New Mexico, FY $1995 \ldots \ldots \ldots \ldots \ldots \ldots \ldots \ldots$

Table 8. Los Alamos National Laboratory Influence on New Mexico's Economy, FY 1995. 14

\section{LIST OF FIGURES}

Figure 1. Los Alamos National Laboratory Three County North-Central New Mexico Region. . . . . . . . . . . . . . . . . . . . 1

Figure 2. Los Alamos National Laboratory Expenditures in North-Central New Mexico by Major Sector, FY 1995. . . . . . . . . . . . 6

Figure 3. Los Alamos National Laboratory Economic Impact on North-Central New Mexico, FX $1995, \ldots \ldots \ldots \ldots \ldots \ldots \ldots \ldots \ldots \ldots$

Figure 4, Los Alamos National Laboratory Expenditures in New Mexico by Major Sector, FY $1995 \ldots \ldots \ldots \ldots \ldots \ldots \ldots \ldots \ldots \ldots$

Figure 5. Los Alamos National Laboratory Economic Impact on the State of New Mexico, FY 1995. 


\section{INTRODUCTION}

Los Alamos National Laboratory is a multidisciplinary, multiprogram laboratory with a mission to enhance national military and economic security through science and techunology. Its mission is to reduce the nuclear danger through stewardship of the nation's nuclear stockpile and through its nomproliferation and verification activities. An important secondary mission is to promote U.S. industrial competitiveness by working with U.S. companies in technology transfer and technology development partnerships. Los Alamos has provided technical assistance to over 70 small New Mexico businesses enabling economic development activities in the region and state.

For several years, the U.S. Departuent of Energy (DOE) Albuquerque Operations Office (AL) and New Mexico State University (NMSU) have maintained an inter-industry, input-output model that has the capability to assess the effect on an economy of developments initiated from outside the ecomomy (exogenous changes on New Mexico)-federal LANL monies that flow into a region or state. This model will be nsed to assess exonomic, personal income, and employment impacts of LANL on north-sentral New Mexico (a thres-county region consisting of Los Alamos, Santa $\mathrm{Fe}$, and Rio Arriba Counties) and the state of New Mexico (Figure 1).

The results of the econometric input-autput (VO) model for FY 1994 are not directly comparable to results of the DOENMSU VO model for LANL for FY 1992 as a new I/O model was developed to estimate economic impacts for FY 1995. The current model is based on new technical information released by the Bureau of Ecomomic Research (BEA), U.S. Department of Commerce. The base year for the FY $1994 \mathrm{I} / 0$ model is 1987. The economic sectors were restructured for the FY 1994 model to reflect economic activity is the state of New Mexico better. In FY 1992 the base year for

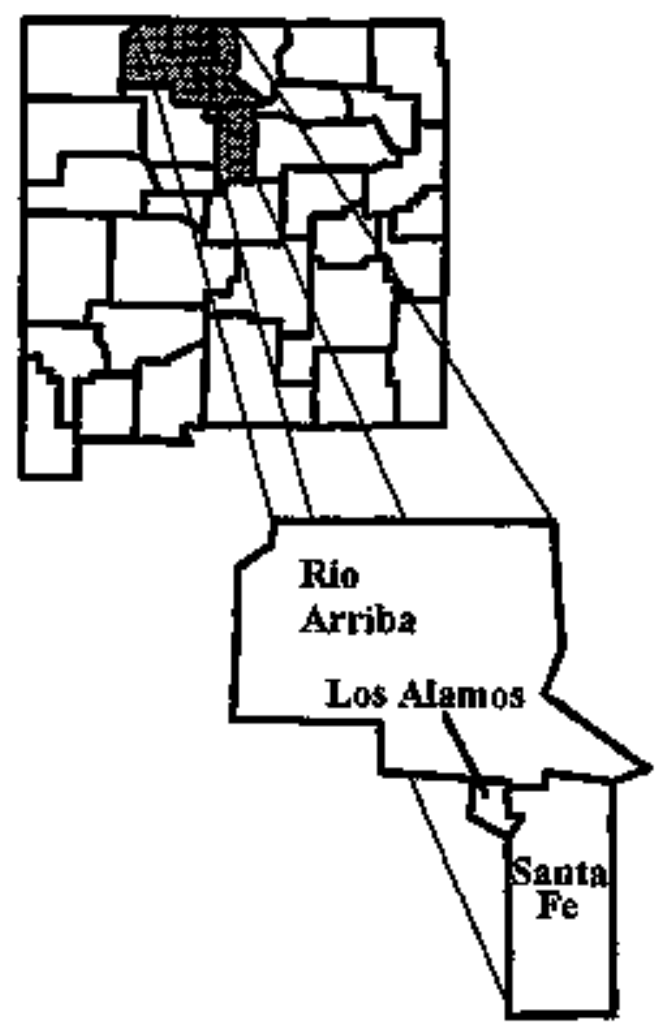

Figure 1. Los Alamos National Laboratory Three County North-Central New Mexico Region. 
the National VO model was 1982 for measuring the LANL sconomic impacts (Lansford et. al., 1993). Futher revised details about the input-output model can be found in "The Economic Impact of the Department of Energy on the State of New Mexico - FY 1994" report by Lansford, et al.

For this report, the reference period is FY 1995 (October 1, 1994, through September 30, 1995) and includes two major impact analyses: the impact of LANL activilies on north-central New Mexico and the economic impacts of LANL on the state of New Mexico. Total impact represents both direct and indirect respending by business, including induced effects (respending by households). The standard multipliers used in determining impacts result from the inter-industry, input-output models developed for the thee-county region and the state of New Mexico.

\section{PROFHE OF LOS ALAMOS NATIONAL LABORATORY}

\section{History}

Las Alamos National Laboratory was established in 1943 as Project Y of the Manhattan Engineering District with the specific responsibility of developing the first nuclear weapon. It became a multi-discipline, multiprogram laboratory applying its capabilities to national needs, defense and civilian issues during the cold-war era.

\section{Background}

The Laboratory is located in Los Alamos County, New Mexico. The county covers 110 square miles and had a 1994 population of 18,521 (Bureas of the Census, 1994). The Laboratory is operated by the University of California for the U.S. Department of Energy under Contract W-7406-ENG-36, and is an affirmative action/equal opportunity employer.

Los Alamos is atso involved in partnerships and collaborations with other federal agencies, universities, and industry. Working with a broad spectrum of partners reflects the fact that the Los Alamos National Laboratory is a national laboratory.
In FY 1995, the Laboratory had 8,558 University of California employees; 1,533 of whom had a doctorate and 3,303 of whom had at least onc technical degree. The operating budget was approximately $\$ 1.2$ billion.

Adrinistrative, research, and maintenance facilitics occupy more than 7.8 million square feet of building space, with 2.3 percent being lessed (off site). The 34 technical areas are scaltered over 43 square miles and occupy about 39 percent of the total county area.

\section{Mission and Capabilities}

The Laboratory's centrol mission is reducing the global nuclear danger, which involves five areas: Stockpile Stewardship, Stockpile Support, Nuclear Materials Management, Non Proliferation and Counter Proliferation, and Environmental Stewardship. A distinguishing feature of the Laboratory is its work in nuclear science. It is responsible for maintaining the safety and operability of the physics package of the nuciear weapons, Los Alamos also applies its expertise to key conventional defente and civilian issues that are synergistic with the central mission and capabilities.

Los Alamos provides techurical assistance to the weapons complex and provides support to such areas as energy and enivironmental technologies. It also emphasizes basic research that sustains existing programs and the DOE research mission, work for other federal agencies, and work with U.S. industry.

The Laboratory's tectmical capabilities are clustered into eight major areas called core technical competencies. The core competencies are characterized by those that emphasize a scientific approach and those that emphesize scientific foundations:

Scientific Approach

- Complex experimentation and measurement

- Theory, modeling, and high-performence computing

- Analysis and Assessment

Scientific Fonndations

- Nuclear weapons, science, and technology

- Earth and environmental systems 
- Nuclear and advanced materials

- Bioscience and biotechnology

- Nuclear science, plasmas, and beams

\section{Major Facilities}

- TA-55 Plutonium Facility. The nation's only full-service operating plutonium facility. Weapons stockpile stewardship, pit surveillance and dismantlement, actinide research, NASA fuel projects, nuclear waste management and treatment.

- Laboratory Data Communication Center (LDCC) plus Alvanced Compiting Laboratory (ACL). Laboratory's central computing facility plus state-of-the-art ACL for advances in high-performance computing.

- Neutron Science Center (LANSCE): National user-facility. Includes the Lujan Neutron Scattering Conter, the Weapons Neutron Research facility, one of the world's most powerful proton linear accelerator, and the proton storage ring. LANSCE supports advanced materials science, nuclear science, partical beam technology, nuclear weapons science, bioscience, and chemistry.

- Chemisty \&Metallurgy Research Factlity (CMR). Plutonium metallurgy, advanced chemical diagnostics, nuclear and tadiochemistry.

- Materfals Science Laboratory (MSL). Materials R\&D centes and user facility, experiments in high-temperature superconductivity, materials modifications and analysis, using ion beams and lasers.

- Healh Research Laboratory (MRL). Center for Human Genome Studies, biological research, molecular biology, biochemistry, genetics.

Achievernents

- Developed first nuclear weapons (1945).

- Demonstrated the ignition of themonuclear fuel (1951).

- Tested first thermonuclear weapon (1952).
- Designed the majority of the weapons in the nuclear stockpile and the fust flash $x$ ray radiographic facility (1963) and holds responsibility for stewardship of the weapons.

- VELA satellite verification of atmospheric test-ban treaty (1963).

- Major contributions to the development of large scale computers and computation and to nuclear reactor design:

MANLAC II computer (1956), IBM's STRETCH (1961), Cray computer (1976), Thinking Machines Corp. CM-2 (198990), Monte-Carlo method (1947) and the $S_{n}$ discrete ordinates method (1953) for solving radiation tansport computations, the particle-in-cell method of numerical fluid dynamics (1957), computer codes to analyze reactor safety (1979). Achievement of criticality: uranium solution-fueled reactor (1944);

First plutonium-fiveled reactor (1946); "Lady Godiva" critical assembly (1953); KIWI reactor (1960); and Phoebus reactor (1965); for nuclear-powered rocket program, and operation of UHTREX reactor (1969).

- Major contributions in fundamenta] science, including:

Detection of neutrino (1956), first demonstration of themonuclear plasma in laboratory fussion studies (1958), use of high intensity LAMPF proton accelerator for nuclear studies (1972), discovery of heavy-fermion superconductor (1982).

- Recent Contribations:

Detection of single fluorescent molecules, first flow cytometer for sorting single biological cells, discovery of the human telomere, complete sequenting of chromoscme 16, measurements of neutrino mass and observation of neutrino oscillations, computer simulation of earth's magnetic field that predicts reversal of the field, computer modeling of global ocean 
temperatures, detection of ionic pulsedpairs of radio inpulses by a detection instrument aboard a satellite, and new milestones in bigh temperature superconductivity and malerials processing.

\section{Future Prospects}

Los Alamos will continue its role in science-based stockpile slewardship. Although defense is expected to decrease; there may be an inctease in the role in non-proliferation and counterproliferation. The Laboratory has been tentatively assigned, in the Stockpile Stewardship and Management Program Programmatic Impact Statement, as the preferred location to manufacture nuclear weapon pits on a small scale. It has also been named as the project office for activities relating to the acceleratorproduction of titium.

\section{ECONOMIC IMPACTS OF LANL ON NORTH-CENTRAL NEW MEXICO,} FY 1995

\section{Funding}

Throughout this chapter, funding to or expenditures by major on-site contractors or LANL will be reficted to as "activities by LANL" for simplicity. The total LANL funding (operating and capital budget) in north central New Mexico in FY 1995 was $\$ 1.2$ billion (Table 1). LANL regional (Las Alamos, Santa Fe, and Rio Arriba Countíes) expenditures were $\$ 704$ million in FY 1995 for salaries and wages, trade and services, capital equipment, and consinuction. University of California operating expendinures accounted for about 86 percent of the total north-central New Mexico expenditures; Johnson Controls funding accounled for 10 percent; and Protection Technologies accounted for 4 percent.

\section{LANL Expenditure Patterns}

Total LANL regional expenditures (the ìnitial respending of the total operating and capital budget) amounted to $\$ 704$ million or about $\$ 9$ percent of the total budget in FY 1995 (Table 1). The five economic sectors accounting for the ntajority of LANL regional expenditures for FY 1995 were househalds ( $\$ 573$ million), other busincss services ( $\$ 28$ million), engineering services (\$23 million), wholesale trade (\$17 million), and retail trade (\$13 million). These sectors combined accounted for just under 93 percent of total LANL regional expenditures (Table l).

LANL expenditures by major sectors in north-central New Mexico for FY 1995 were personnel, (including benefits) (\$573 million), services ( $\$ 70$ million), trade ( $\$ 30$ million), government (\$11 million), manufacturing (\$9 million), other sectors (\$8 million), and constuction ( $\$ 4$ million) (Table 2). By far the largest LANL expenditure in north-central New Mexico was labor, 81 percent of the total regional expenditures. In FY 1995, 10 percent of the LANL expenditures went for services, 4 percent for trade, 1.6 percent for government, I.3 percent for manufacturing, 1,1 percent for other sectors, 1 percent for transportation communication and utilities, and less then one percent for construction (Figure 2).

\section{Employment}

LANL is managed and operated by the University of California with approxirnately 8,113 employees in the three-county region in FY 1995 (Table 3). Johnson Controls had 1,524 ful]-time employees in FY 1995 and Protection Technologies had 439 employees. Subcontractors averaged 2,000 employees. The total number of jobs (al] types of personnel) region-wide paid by the federal govenment or by contracts directly associated with LANL averaged 10,076 for FY 1995.

\section{Measuring the LANL Economic Impact on North-Central New Merico}

The analysis of the DOE/New Mexico economic impact on north-central New Mexico emaployed an connomic model that incorporates buying and selling linkages among regional industries. This antlysis measures the impact generated by LANL and contractors expending money in the three north-central counties (Los Alamos, Santa $\mathrm{Fe}$, and Rio Arriba) of New Mexico.

Several useful products of the $1 / O$ modeling technique are multipliers. Three multípliers (the first related to general economic activity, the second to 


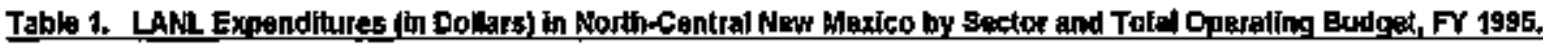

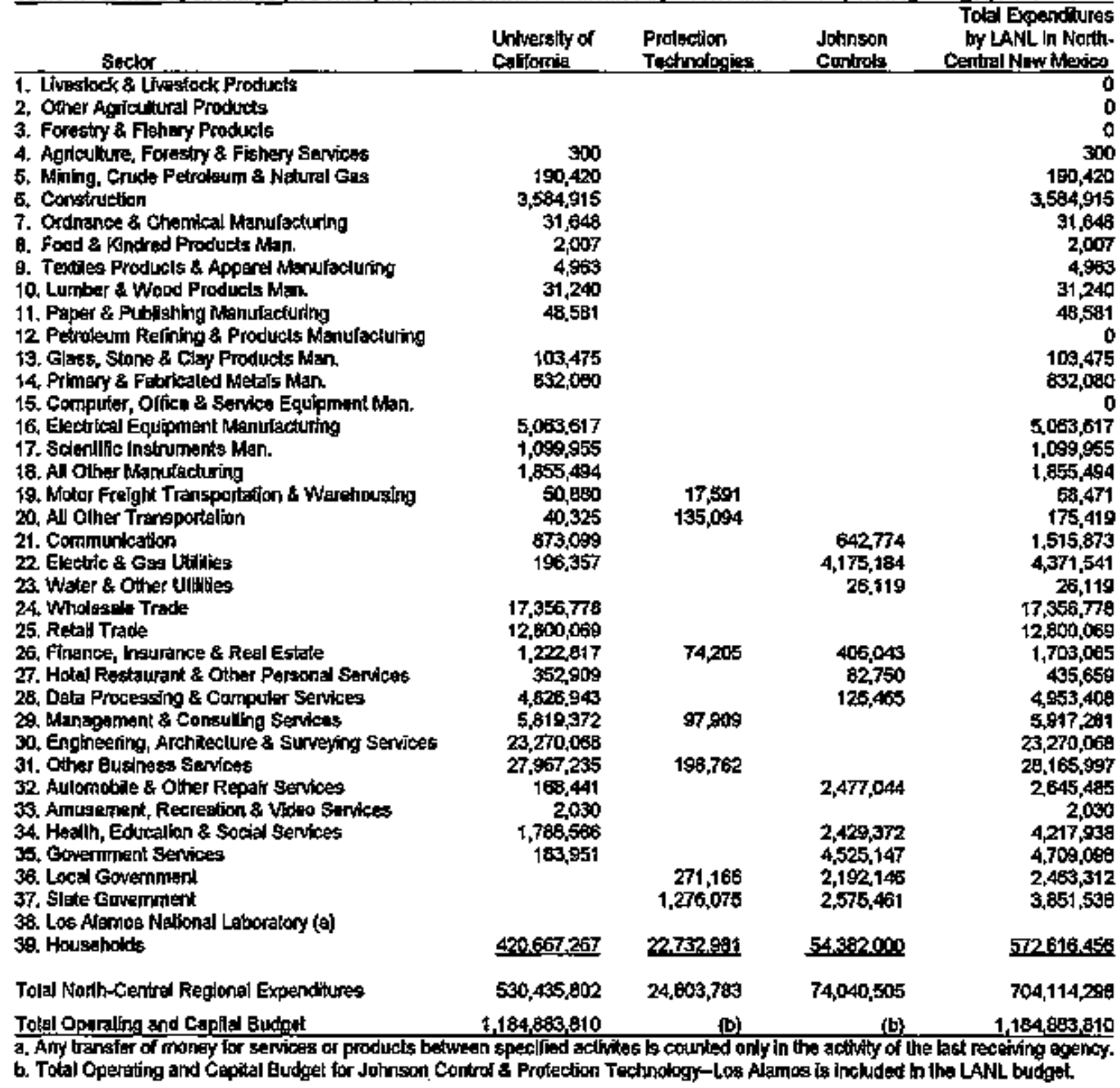

income, and the third to employment) provide in 'onmation needed to estimate LANL's impact. The activity multiplier identifies the extent to which an activity such as LANL relies directly and indirectly on the regional econoruy to provide it with the materials, services, and labor it requires to conduce its activities, and the extent to which respending by businesses and inderstries occurs in the region. lncome and employment multipliers make possible the identification of not only the direct impacts of an activity on income and jobs but also the indirect (business) and induced (households) effects.

\section{Economic Impact of LANL}

The flow diagram (Figure 3) charts the movement of monies spent by LANL. Expenditures for salaries and purchases go to households, regional businesses, and other regions (outside the three- 
Table 2. Los Alamos National Laboratory Expendltures in North-Central New Mexico by Major Sector, FY 1995. FY-1906 thousands Sectoro of dollars

\begin{tabular}{|c|c|c|c|}
\hline \multicolumn{4}{|c|}{ i. Personned } \\
\hline & Salanies \& Wages & 452,594 & $84.3 \%$ \\
\hline & Eengits & 12.002 & $17.0 \mathrm{~s}$ \\
\hline & Total & 572,616 & $05.3 \%$ \\
\hline II. & Construction & 3,585 & $0.5 \%$ \\
\hline III. I & Menufacluring & 9,073 & $\$ 3 \%$ \\
\hline IV. & Trode & 30,157 & $4,3 \%$ \\
\hline V. & Service & 69,608 & $9.9 \%$ \\
\hline \multicolumn{4}{|c|}{ vi. Govemment } \\
\hline & A. Locat Contommenk & 2,463 & a.3\% \\
\hline & B, Skte Gowemment & 3,852 & $0,5 \%$ \\
\hline & c. Boverningent Servie & 684.709 & 0,78 \\
\hline & Total & 11,024 & $5.6 \%$ \\
\hline
\end{tabular}

V. Other Seclart
A. Agriathr:
B. Aining
o 0,0 s(a)
C. T,C.L.,(b)
150
$0.05(a)$
D. F.I.R.E(c)
6.157
$0.8 \%$
Tot:al
1.703
8.051
$0.2 \%$
$1.1 \%$

TOTAL EXPENDITURES 704.114 100.0\%

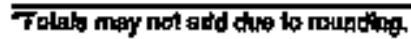

a Less then $1 / 10$ of one peroum

b. Transpontation, Communkcations and Utilites

c. Fnance, lowernance and Regl Estrile
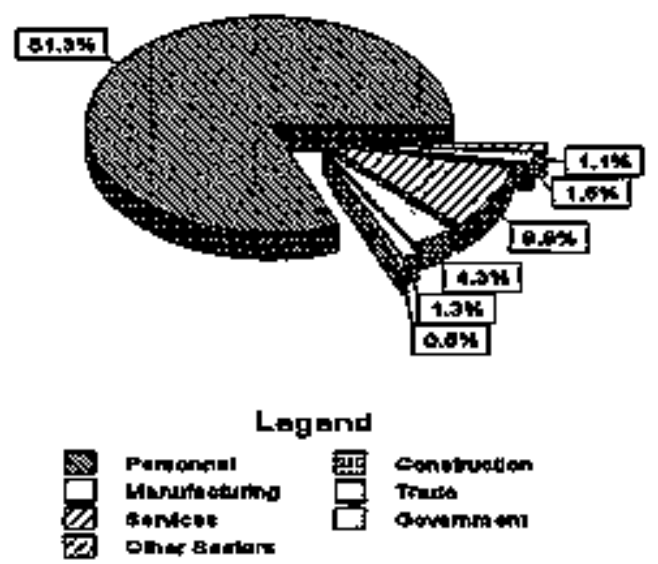

Figure 2. LANL Expenditures in North-Central New Mexico by Aajor Sector, FY 1995. county region of New Mexico). This injection of money affects economic activity directly: the effect equals the amount funded for LANL efforts in north-central New Mexico (\$1,2 billion).

Households and businesses affected by LANL respend muxh of the money they receive in the three-county region, thus creating indirect (business) and incuced (househoId) effects. In turn, businesses buy from other local firms and pay salaries to their employees, starting another round of sponding. Every mowement of money around the circle causes additional indirect (and induced) effects. However, sone funds leak outside the region when purchases are made elsewhere and are not available for further local spending. Thus, indirect effects become srialler and smaller as continued respending occurs.

The initial spending by LANL generates substantial first-round impacts on households (net) and businesses (\$503 and \$121 million, respectively for FY 1995) in the three-county north-central region (Figure 3). This initial spending will provide govenument $\$ 11$ miltion in new sevenues (mainly stafe and local government taxes and fees). However, a large portion of the initial spending (\$481 million) and transfer payments, including fringe benefits costs to tabor ( $\$ 46$ million), flow out-of-state through leakages.

Respending by regional businesses and purchases by households and state and local government

Table 3. LANL Funding, Region Expenditures and Employment by Major Entity in North Central New Mexico, FY 1995.

\begin{tabular}{|c|c|c|c|}
\hline Entity & $\begin{array}{l}\text { Naw } \\
\text { Meroico } \\
\text { Funding }\end{array}$ & $\begin{array}{l}\text { Regitonat } \\
\text { Expend- } \\
\text { itures }\end{array}$ & $\begin{array}{l}\text { New Hexico } \\
\text { Reglonal } \\
\text { Emplomimant }\end{array}$ \\
\hline & \multicolumn{2}{|c|}{-millons of doldariso. } & (cobs) \\
\hline $\begin{array}{l}\text { Lniv, of Cactornir } \\
\text { (LANL) } \\
\text { Johnson Controls }\end{array}$ & $t, 164.8$ & 530.4 & 8,113 \\
\hline PT-LA & (a) & $\begin{array}{l}74.0 \\
24.8 \\
\end{array}$ & $\begin{array}{r}1,524 \\
\underline{439}\end{array}$ \\
\hline Tod리 & $1.184,8$ & 629.3 & 10,076 \\
\hline
\end{tabular}


eventually bring the total private business impact to about $\$ 965$ million. Also, respending activity will continue to add to personal income and government revenues so that total personal income will increase to $\$ 1.07$ million, and state and local govermment tax revenues and goverument fees will expand $\$ 140$ million as a result of direct, indirect, and induced effects.

\section{Overall Impact}

Using LANL's funding for its total operating and capital buxiget of $\$ 1.2$ billion, econometric modeling techriques were used to calculate the effects of this finding. As Table 4 indicates, the total increase in economic activity in New Mexico was \$3.4 billion from the initial infusion of $\$ 1.2$ billion. The economic activity multiplier measures the volume of activity generated among various sectors of a region as a result of a \$1 exogenous change in a sector. For example, the cconomic activity multiplier for LANL for FY 1995 was 2,89. This indicates that for every
$\$ 1$ spent by LANL and its major on-site New Mexico contractors, another $\$ 1.89$ was generated for a total impact of $\$ 2.89$ in FY 1995.

No official figure exists for total economic activity in the three-county north-central region; however, for the purposes of this study total economic activity in the three-county region is estimated at \$11.35 billion for 1995 (Table 4). Applying the regional economic activity multiplier of 2.89 to the $\$ 1.2$ billion directly added to the regional economy results in the $\$ 3.4$ billion estimated total inforact in FY 1995. This total impact of $\$ 3.4$ bilition genserated by LANL is about 30 percent of the estimated $\$ 11.35$ billion total economic activity in the region. Table $A$ gives the direct, indirect, indnced, and total economic activity impact of LANL on the region,

Table 11 in the Appendix gives LANL indirect sconomic impacts on private and public sectors for FY 1995. The retail trade sector received the greater volume of indireet private and pablic economic

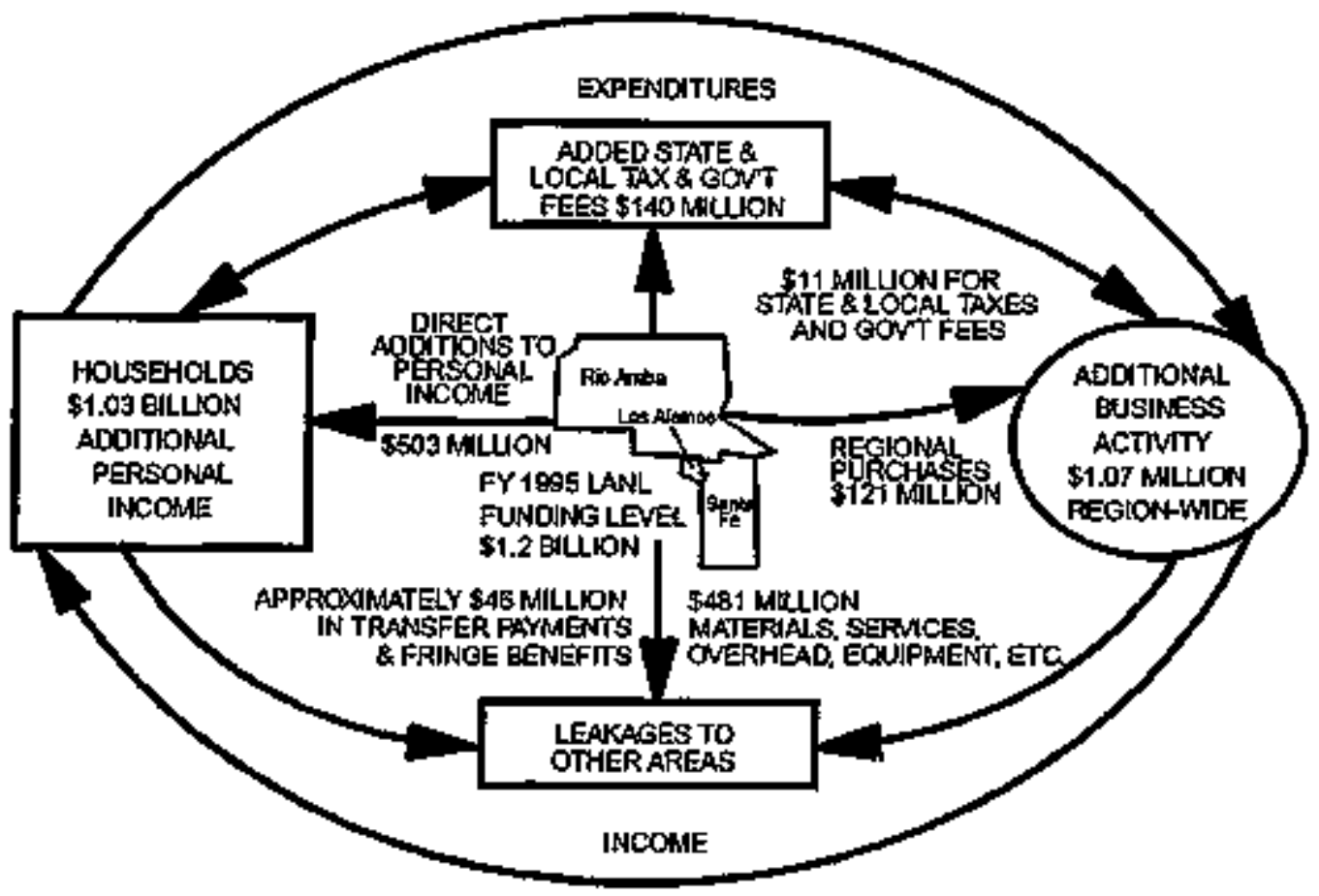

TOTAL REGION+WIDE ECONOHIC INIPACT - \$3,4 BILLION

Figure 3. Los Alamos National Laboratory Economic Impact on North-Central New Mexico, FY 1995. 
Table 4. Los Alamos National Laboratory Regional Influence on North-Central New Mexico's Economy, FY 1995.

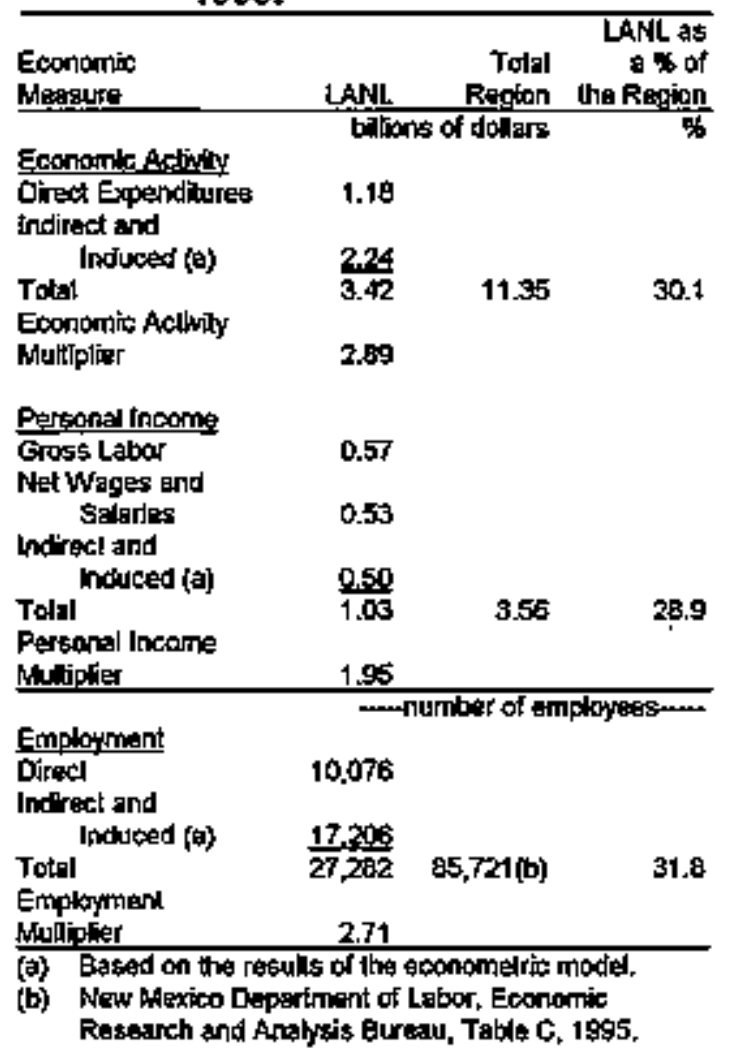

impacts, about 19 percent of the total estimated indirect impacts. Other seciors with large indirect conomic impacts include finance, insurance and real estate (FIRE) ( 17 percent), electric and gas utilitics (6 percent), hotel, restararant, and otber personal services ( 6 perecent), and health, education, and social services (6 pereent).

\section{Impact on Income}

Personal income is money that goes to individuals that will be respent for purchases such as groceries, automobiles and gasolise, mortgage pnyments, medical, new shoes, taxes and savings. Most personal income consists of wages and salaries, although payments received as interest, rent, dividends, and social security benefils (payments to individuals) also count as personal income. Some of the fringe beneffts and wages paid to employees are not counted in the current income stream (i.e., social security payments by employers and cmployees). In FY 1995, labor paymenis of $\$ 573$ million resulted in an estimated $\$ 503$ million in net additional personal income to the region.

Income mullipliers measure the indirect and induced eftects from now incame generated from payment to labor by LANL. The income multiplier was 1.95 for FY 1995 (Table 4). Applying the incone multiplicr of 1.95 to the ditect net personal income figure of $\$ 503$ million yields a total impact of $\$ 1,03$ billion for income in the region resulting from LANL activity. This multipliet indicates that for every $\$ 1$ of personal income from LANL for labor, another $\$ 0.95$ is gencraled through indirect and induced e[fects, for a total impact on personal income of $\$ 1.03$ billion.

In FY 1995, total personal income in north-central Nenv Mexico vas estimated at $\$ 3.56$ billion (Table 4). LANL activities in the north-central New Mexico region accounted for about 29 percent of total regional personal income in 1995.

\section{Impact on Employment}

Beside this dollars-and-cents impact, LANL aflects region-svide employment In addition to the average of 10,076 minly full-time jobs created by LANL in FY 1995, other jobs are supported by the resulting needs for goods and services and respending by individuals and businesses. Firus filling those needs have their own employees and jin turn, spend money with other fims who must also hire people. In atdition, each individual employee needs goods and services and helps support other jobs such as waitresses, mechanics, clerks, lavyers, and nurses.

The employment multipliers measure the number of indirect and indiced jobs supported, on the average, by LANL. The regional employment multiplier for LANL was estimated to be 2.71 in FY 1995 (Table 4). This indicates that for every 100 jobs created by LANL, another 17! jobs were supported in FY 1995, translaling to a total impact of 27,282 jobs. These 27,282 jobs created or supported by LANL acoounted for about 32 percent of total employment in the region in FY 1995 (Table 4). 
Table 11 in the Appendix gives the LANL indirect employtnent impact of private and public sectors for FY 1995. The more labor-intensive sectors received the greater indirect employment impact. The retail trade sector hat the fargest indirect inpact of about 29 percent. Other sectors with a large indirect employtuent inpact include FIRE (11 percent), hotel, restaurant and other personal services (10 percent), heatth, education and social services ( 8 percent), and other business services (5 percent).

\section{CONCLUSIONS}

In summary, LANL operations in north-central New Mexico have a siguificant and positive influence on the economy of north-central New Mfexico. The funding for LANL in north-central New Mexico was about $\$ 1.2$ billion in FY 1995 , yielding a total economic impact of over $\mathbf{5 3 . 4}$ billion or about $\mathbf{3 0}$ percent of the total economic activity in the region.

Total personal income impact was $\$ 1.03$ billion in FY 1995 or 29 percent of personal income derived in the three counties. The employment multiplier was 2.71 for the region, meaning that the 10,076 average employment level of FY 1995 supported a total impact of 27,282 . In effect, one of nearly every 3 jobs in the region was created or supported by LANL. Approximately 78 percent of the jobs created indirectly by LANL in the region occurred in the trade and services sectors.

\section{ECONOMIC IMPACTS OF LANL ON THE STATE OF NEW MEXICO, FY 1995}

\section{Funding}

Throughout this chapter, funding to or expenditures by major on-site contractors or LANL offices will be referred to as activities by LANL for simplicity. The state-wide total funding (operating and capital budget) for LANL for FY 1995 was $\$ 1.2$ billion (Table 5). LANL expenditures were $\$ \$ 75$ million in FY 1995 for salaries and wages, trade and services, capital equipment, and coustruction. University of Califormia expenditures accounted for 87 percent of the total New Mexico expenditures; Johnson
Controls funding accounted for 10 percent; and Protection Techunologies accoumted for 3 percent. The largest contractor supporting the LANL project in the state of New Mexico was Johnson Controls.

\section{LANL Expenditure Patterns}

Total LANL in-state expenditures (the initial respending of the total operating and capital budget) amounted to about 74 percent of the total budget in FY 1995 (Table 5). Johnson Controls total in-state expenditures in New Mexico were \$86 million. Actual LANL in-state expenditures were \$875 millios in FY 1995 for salaries and wages, trade and services, capital equipment, and construction (Table 5).

Out-of-state purchases and salaries for those living elsewhere antounted to $\$ 308$ million. In addition, approximately $\$ 48$ million for transfer payments and some fringe benefit costs for in-state labor costs leaked directly out of state. The six economic sectors accoumting for the majority of LANL in-state expendinures for FY 1995 were households (\$609 million), retail trade (\$56 million), wholesale trade (\$5t million), other business services (\$37 mullion), and engineering, architecture, and surveying (\$28 million). These sectors combined accounted for 89 percent of total in-state LANL expenditures in FY 1995.

LANL expenditures by mejor sectors in New Mexico for FY 1995 were personnel inciuding benefits ( $\$ 609$ million), trade ( $\$ 107$ million), services (\$101 million), govemment (\$15 million), manufachuring (\$13 million), constnuction (\$8 Irillion), and ocher sectors ( $\$ 23$ million) (Table 6). By far the largest expenditure by LANL in the state of New Mexico was labor (\$609 miltion), which is nearly 70 percent of the state-wide expenditure (Table 6), or 51 percent of the total operating and capital budget for FY 1995 . Salaries and wages (without benefit costs) accounted for $\$ 6$ percent of the total in-state expenditures. In FY 1995, about 12 percent of LANL expenditures went for trade, 12 percent to services, 2 percent to transportation, commumication, and utilities, 2 percent for manufacturing, 2 percent went to goverment, and about 1 percent for construction and the other seclors (Figurs 4). 
Table 5. LANL Expenditures (in Dollars) In New Mexico by Sector and Total Operating Budget, FY 1995.



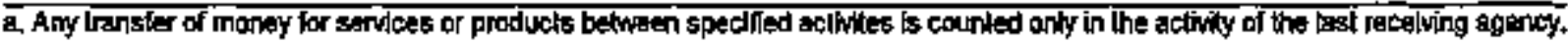

b. Total Operating and Capital Budgat tor Johnsan Control \& Protaction Technolagy-Los Alemos is inoluded In the LANL budgat.

\section{Employment}

LANL is managed and operated by the Unjversity of Califomia, with approximately 8,558 full-time employees state-wide in FY 1995. Johinson Controls had 1,524 full-time employees in FY 1995, and Protection Technologies had 439 employees each (Table 7). The total number of jobs (all types of personnel) state-wide paid by the federal government or by contracts directly associated with LANL averaged 10,521 for FY 1995. 

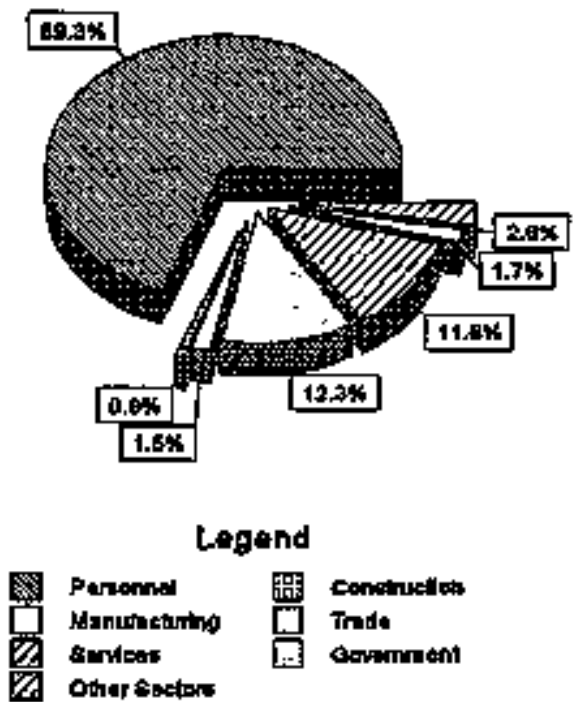

Figure 4. LANL Expenditures in New Mexico by Major Sector, FY 1995.

Measuring LANL's Economic Impact on New Mexico

The analysis of DOENNew Mexico economic impact on New Mexico employed an economic model that incorporates buying and selling linkages anong regional industries. This analysis meastures the impact generated by LANL, the DOE/AL contractor expending money in the state. As previously staled, the term DOENNew Mexico is used to describe all these entities.

Several useful products of the 10 modeling techunique are multipliers. Three multipliers-the first related to general economic activity, the second to income, and the third to employment-provide the infomation needed to estimate LANL's impact. The activity multiplier joentities the extent to which an actirity such as LANL reclies directly and indirectly on the state's economy to provide the materials, services, and labor it requires to conduct its activities, and the extent to which respending by businesses and industries occurs in the state. Income and employment multipliers make it possible to identify not only the direct impacts of an activity on income and jobs, but also the indirect (business) and induoed (houscholds) effects.
Table 6. LANL Expenditures in New Mexico by Major Sector, FY 1995.

\begin{tabular}{|c|c|c|c|}
\hline Settor & & $\begin{array}{l}\text { FY-1955 } \\
\text { thotsands } \\
\text { of tollaris }\end{array}$ & (\%) \\
\hline \multicolumn{4}{|c|}{ t. Personal } \\
\hline & abarles \& Wagos & 483,890 & $55.6 \%$ \\
\hline & eneifits & $12172 ?$ & $139 \%$ \\
\hline & Total & 608,612 & $69.5 \%$ \\
\hline t. & insiruction & 8,230 & $0.9 \%$ \\
\hline th. & anufacturing & 12,909 & $1.5 \%$ \\
\hline N. T & racto & 107,041 & $122 \%$ \\
\hline $\begin{array}{l}\text { v. } s \\
\text { vi. }\end{array}$ & $\begin{array}{l}\text { ertce } \\
\text { iovernment }\end{array}$ & 101,078 & $11.5 \%$ \\
\hline A. & Lacal Govemmant & $\begin{array}{l}2,965 \\
4792\end{array}$ & $0.9 \%$ \\
\hline c. & $\begin{array}{l}\text { Gowemmend Servires } \\
\text { Toka }\end{array}$ & $\frac{7.240}{14,898}$ & $\frac{0.8 \%}{1.7 \%}$ \\
\hline
\end{tabular}

VI. Oliw Sectors

$\begin{array}{lrr}\text { A. Agictuture } & 5 & 0.0 \% \text { (a) } \\ \text { B. Mints } & 1,306 & 0.1 \% \\ \text { C. T.C.U.(b) } & 19,511 & 22 \% \\ \text { D. F.I.R.E(c) } & 1,709 & \underline{0.2 \%} \\ \text { Total } & 22,627 & 26 \%\end{array}$

TOTAL EXPENDITURES $\quad 875,390 \quad 100,0 \%$

Tolak mar not aod due rounding.

8. Lese Man 1/10 of ane pationt

b. Trassporision, Commindcarlons and Wuilies

c. Financos, Inaurenca and Reol Ealala

Table 7. LANL Funding, Instate Expenditures and Employment by Major Entity In New Mexico, FY 1995.

\begin{tabular}{|c|c|c|c|}
\hline Entity & $\begin{array}{r}\text { Nerw } \\
\text { Wexico } \\
\text { Findin? }\end{array}$ & 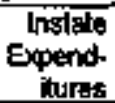 & $\begin{array}{l}\text { New Mexico } \\
\text { Emplormeni }\end{array}$ \\
\hline & \multicolumn{2}{|c|}{ - m|l|ans of danlars } & (obs) \\
\hline $\begin{array}{l}\text { Uniry of Galformita } \\
\text { (LANL) }\end{array}$ & $1,184.9$ & 769.5 & $a, 558$ \\
\hline $\begin{array}{c}\text { Johnson Conhrołs } \\
\text { (LAkL) }\end{array}$ & (b) & 856.0 & 1,524 \\
\hline Protetive Technologips & [b] & 25.9 & 430 \\
\hline Totet & 1,1849 & 875.4 & 10,521 \\
\hline
\end{tabular}




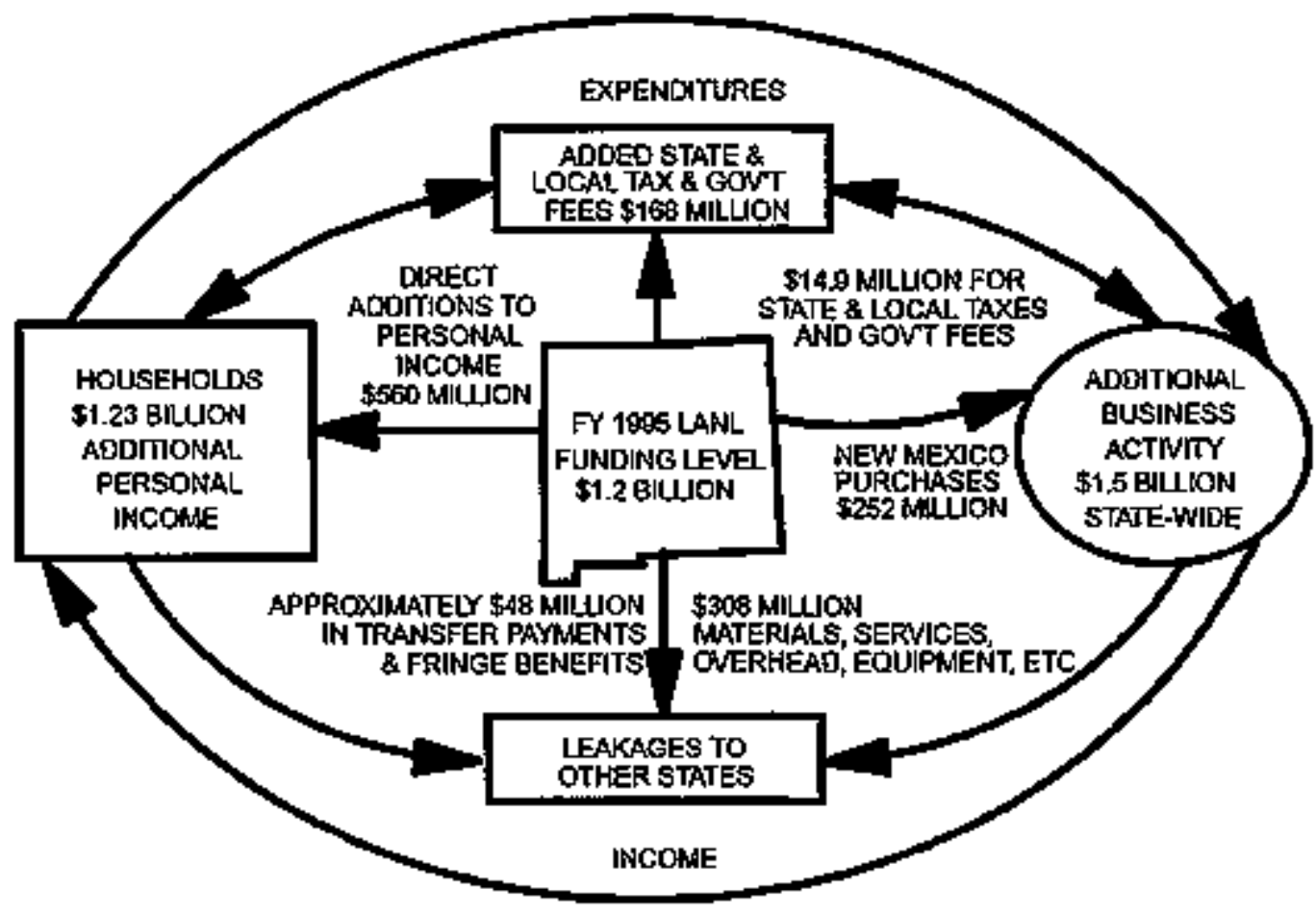

TOTAL STATE-WIDE ECONOMIC IMPACT - $\$ 4.09$ BHLION

Figure 5. Los Alamos National Laboratory Economic Impact on the State of New Mexico, FY 1995.

\section{Eonomic Impact of LANL}

The flow diagram (Figure 5) charts the movement of monies spent by LANL. Expenditures for salaries and purchases go to households, state-wide businesses, axd other regions (outside the state of New Mexico). This injection of money affects economic activity directly, that is, the effect equals the amount allocated to LANL ( $\$ 1.2$ billion).

Households and businesses affected by LANL respend much of the money they receive in the state, thus creating indirect (business) and induced (houschold) effects. In tum, businesses buy from other local firms and pay salaries to their employees, stanting another round of spending. Every movement of money around the circle canses additional indirect (and induced) effects. However, some funds leak outside the region (state) when purchases are made elsewhere and are not available for further local spending. Thus, the ixdirect effects become smaller and straller as continued respending occurs.
Initial spending by LANL generates substantial furst-round impacts on households (net) and businesses: $\mathbf{5 6 0}$ and $\$ 252$ million, respectively for FY 1995 (Figure 5). This initial spending will give government $\$ 15$ million in new revemes (mainly state and local govenument taxes and fees); however, a large portion of the initial spending (\$308 million, plus \$48 million in transfer payments and some fringe bencfit cosis) flows out of state through leakages.

Respending by in-state businesses and purchases by households and state and local goverments eventually bring the total private business impact to $\$ 1.5$ billion. Also, respending activity will continue to add to personal income and government revenues so that the total personal income effect will increase to $\$ 1,2$ billion, and state and local government tax revenues and government fees will expand \$168 million as a result of direct, indirect, and induced impacts. 


\section{Overall Impact}

No official figure exists for total economic activity in the state; however, for this study, a 1995 estimate of $\$ 84.6$ billion is ased (Table 8 ), While LANL is an important economic factor in north-cestral New Mexico, the ecomomic impacts are important but less significant when measured on a state-wide basis. LANL dircetly added \$1.2 billion to the total state econorny in FY 1995. The estimated indirect (and induced) impact of $\$ 2.91$ billion brings the total irnpact to $\$ 4.09$ billion or about 5 percent of the estimated $\$ 84.6$ billion state-wids total activity in $\mathbf{1 9 9 5 .}$

The estimated $\$ 4.10$ billion total economic impact in New Mexico from the initial infusion of $\$ 1.2$ billion is derived from 10 modeling techniques employed in the stuxty. The modelinig process produces estimated impacts from which muttipliers can be determined. The economic activity multipliers are used to measure the volume of activity gemerated anong various sectors of a region as a result of a SI exogenous change in a sector.

For example, the economic activity multiplier for LANL for FY 1995 was 3.45. This indicates that for every $\$ 1$ spent by LANL or its major on-site contractors, another $\$ 2.45$ was generated, for a total impact of $\$ 3.45$ in FY 1995. Table 8 gives the direct, indirect, incluced, and total economic activity impact of LANL on the state.

Appendix Table 12 gives LANL indirect economic impacts on pivate and public sectors for FY 1995. The retail trade sector received the gereatest volume of indirect econotric irapacts, bbout 19 percent of the total estimated public and private sector volume of indirest impacts. Other sectors with [arge indirect impacts were FIRE ( 15 percent), wholesale trade ( 6 percent), other business services ( 6 percent), hotel, restaurant and other personal services (6 percent), and electric and gas utilities ( 5 percent).

\section{Impact on Income}

Personal inoome is money that goes to individuals to be respent for items such is groceries, automobiles and gasoline, mortgage payments, medical, new shoos, taxes, and savings. Most personal income consists of wages and salaries, although payments received as interest, rent, dividends, and social security benefits (payments to individuals) also count as personal income. Some of the tringe benefits and wages paid to employees are not counted in the current income stream (i.c., social security payments by employers and employees). In FY 1995, labor payments of $\$ 609$ million resulted in an estimated $\$ 560$ million in net additional personal incorne.

Income nmultipliers measure the indirect and induced effects of new income generated from payment to jabor by LANL. The income multiplier was 2.19 for FY 1995 (Table 8). Application of the income multiplier of 2.19 to the direct net personal income figure of $\$ 560$ million yields a total impact of $\$ 1.23$ billion for income resulting from LANL activity. This multiplier indicates that for every $\$ 1$ of personal income from LANL for laber, another $\$ 1.19$ is generated through indirect and induced effects, for a tofal impact, on personal income of $\$ 1.23$ bjlition.

In FY 1995, total personal income in New Mexico was estimated at $\$ 30.4$ billion (Table 8). LANL activities in the New Mexico accourted for slightly over 4 percent of total personal income in 1995.

\section{Impact on Employment}

Beside this dollars-and-cents inpact, LANL affects state-wide employnent. In addition to the average of 10,521 mainly full-time jobs created by LANL in FY 1995, other jobs are supported by needs for goods and services and respending by individuals and businesses. Firms filling those needs have their own employes and in turn, spend money with other firms who must also hire people. Additionally, each individual cmployee demand goods and services and therefore supports other jobs such as waituesses, mechanics, clerks, lawyers, and nurses.

Employment muttipliers measure the number of indirect and induced jobs supponted, on the average, by LANL. The empioyment multiplier for LANL was estimated to be 3.23 in FY 1995 (T2ble 8). This indicates that for every 100 jobs created by LANL, another 223 jobs were supported in FY 1995, a total impact of 33,961 jobs. The total impact of 33,96 t jobs created or supported by LANL accounted for 
Table 8. LANL Infiuence on New Mexico's Economy, FY 1995.

\begin{tabular}{|c|c|c|c|}
\hline $\begin{array}{l}\text { Eoonomic } \\
\text { Weastre }\end{array}$ & LANL & $\begin{array}{r}\text { Totel } \\
\text { Stale } \\
\end{array}$ & $\begin{array}{r}\text { LANL as } \\
\text { a \% of } \\
\text { lhe State }\end{array}$ \\
\hline & \multicolumn{2}{|c|}{ binions of dollars } & $\%$ \\
\hline $\begin{array}{l}\text { Econom.'. Actinty } \\
\text { Dirsch Expenditures }\end{array}$ & 1.18 & & \\
\hline Induced (a) & 2.91 & & \\
\hline $\begin{array}{l}\text { Total } \\
\text { Economic Activlty } \\
\text { Muthiplier }\end{array}$ & $\begin{array}{r}4.09 \\
3.45\end{array}$ & 84.6 & 4.8 \\
\hline \multicolumn{4}{|l|}{ 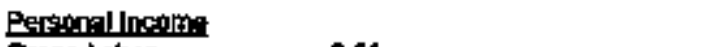 } \\
\hline $\begin{array}{l}\text { Gross Lopor } \\
\text { Net Wages and }\end{array}$ & 0.61 & & \\
\hline $\begin{array}{l}\text { Selaries } \\
\text { [rowinect and }\end{array}$ & 0.56 & & \\
\hline Inciuced $(a)$ & 0.66 & & \\
\hline $\begin{array}{l}\text { Total } \\
\text { Persenal incorno } \\
\text { Mullipter }\end{array}$ & $\begin{array}{l}1.22 \\
2.19\end{array}$ & $30.4(0)$ & 4.0 \\
\hline 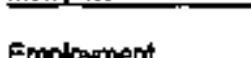 & \multicolumn{3}{|c|}{-number of employeses- } \\
\hline $\begin{array}{l}\text { Einowinem } \\
\text { Direct } \\
\text { Indirect and }\end{array}$ & 10,521 & & \\
\hline 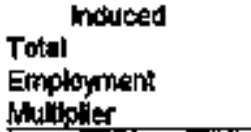 & $\begin{array}{r}\frac{23,440}{33,961} \\
3,23 \\
\end{array}$ & $738,400(c)$ & 4.6 \\
\hline
\end{tabular}

(a) Based on the resutis of the economeitic moded.

(b) Less then 1/10 of one percent

(c) Tolele may not add due to rounding.

4.6 percent of total employment in the state in FY 1995 (see Table 8).

Table 12 in the Appendix gives LANL indirect employment impact on the private and public sectors for FY 1995. The more labor-mintensive sectors received the greater indirect employment impact. The retail trade sector had the largest indirect impact, about 29 percent of the indirect impact. Other sectors with a large indirect employment impact include lodging and personal services (11 percert), FIRE (10 percent), and health and social services ( 8 percent).

\section{CONCLUSIONS}

In strmary, LANL operations in New Mexico have a significant and positive influence on the economy of New Mexico. The funding for LANL in New Mexico, about $\$ 1.2$ billion in FY 1995, supperted a total economic impact of $\$ 4.1$ billion or slightly less then 5 percent of total economic actiyity in the state.

Total personal income impacts were over $\$ 1.2$ biltion in FY 1995 or 4 percent of personal income derived in New Mexico. The employment multiplier was 3.23 for the state, meaning that the 10,521 average employment level in FY 1995 supported a total impact of 33,961. In effect, one of nearly every 20 jobs in the state was created or supported by LANL. Approximately 80 percent of the jobs created indirectly by LANL in the region occurred in the trade and services sectors. 


\section{REFERENCES}

Adcock, Larry. "Effective Tax Rates for New Mexico, 1986." Los Alamos National Laboratory. Unpublished marruscript, Los Alanos, New Mexico.

Adcock, L,D., T.M Cohen, R.R. Lansford, DJ. Post, and S.L. Rumyon, 1992, "The Social and Economic Impacts of the Department of Energy on the State of New Mexico, FY 1991." U.S. DOE Albuquerque, Albuquerqque Operations Ofitce, Albuquerque, NM.

Adcock, L.D., and R,R. Lansford, 1991, "The Social and Economic Impacts of the Department of Energy on the State of New Mexico, FY 1990" U.S. DOE Albucquerque, Albuquerque Operations Office, Albuquerque, NM.

Adcoek, L.D., and R.R. Lansford, 1990, "The Social and Economic Impacts of the Department of Energy on the State of New Mexico, FY 1989." U.S. DOE Albuguerque, Albuquerque Operations Office, Albuquerque, NM.

Adcock, L.D., R.R Lansford, and A. Turpin, 1989. "The Social and Economic Impact of the Department of Energy on the State of New Mexion, FY 1988." U.S. DOE Albuquerque, Albucgserque Operations Office, Report No. APD-89-2, Albuquerque, NM.

Adcock, Lanry and Lany Waldman, "A Non-Survey Technique for Constructing a Direct Requirements Regional Input-Output Table." Proceedings 1975 Conference of the Association foc University and_Business Research, Virginia, edited at Arizona State University, Tempe, Arizonas,

Carruthers, Garrey, K. Mitcheli, and Thomas Williams, 1972. "An Inter-industry Model of the Economy of Norti-Central New Mexico," Agricultural Experiment Station Research Report 237, New Mexico State University, Las Cruces, New Mexico.

Cohen, T.M., L.D. Adcock, and R.R. Lansford, 1992. "The Economic Inpact of Los Alamos
National Laboratory and Sandia National Laboratories on the State of New Mexico FY 1990." Agriculbural Experiment Station, Technical Report 7, New Mexico State University, Las Cruces, NM.

Lansford, R.R, L.D. Adcock, S. Ben-Dovid, and S.L. Renyor, 1993, "The Economic Impact of the Department of Energy on the State of New Mexico FY 1992." U.S. DOE Albuquerque, Albuquercque Operations Ofifice, Albucquerque, NM.

Lansford, R.R., J.A. Diemer, E.M. Jaramillo, A Turpin, D. Williams, V. Devers, and L, Adpack, 1988. "The Social and Economic Impact of the Department of Energy on the State of New Mexico, FY 1987," Special Report 79, Agricultural Experiment Station, New Mexico State University, Las Cruces, New Mexico.

Morris, Donald, Lany Adcock, Steven Booth, 1986. "Los Alamos National Laboratory: A Regional Economic Impact Stuxy," Los Alamos National Laborstory Report LA-UR-3206, Los Alamos, New Mexico.

New Mexico Department of Labor, April 1989. "New Mexico Labor Market, Annual Planning Report, ${ }^{n}$ Bureau of Economic Research and Analysis, University of New Mexico, Albuquerque, New Mexico.

New Mexico Deparment of Labor, January 1991. "Covered Employment and Wages," Quarterly Report, Quarter 1989 and First Quarter 1990; Economic Research and Analysis Bureau, Albuquerque, New Mexico.

New Mexico Department of Labor, April 1993. "Table A," Economic Research and Analysis Burealls, Albuquerque, New Mexico.

New Mexico Departrnent of Labor, "Report of Employment, Wages, and Contributions (Es-202)," Economic Research and Analysis Bureats, Albuquerque, New Mexico; unpublished information.

Runyor, Shannon L, 1993. Effective Tax Rates for New Mexico by Economic Sector, M.S. thesis, 
New Mexico State University, Las Cruces, May.

Sunwest Financial Services, Inc., 1992, "New Mexico Progress, Economic Review of 1991," in draft; Sunwest Financial Services, Inc. P. 0 . Box 25500, Albuquerque, NM 87125.

Turpin, Annette, Larry Adcock, and Donna Williams, 1987. "The Economic Impact of the Uniled Stales Departmemt of Energy on the State of New Mexico Fiscal Years 1985 and 1986," Los Alamos National Laboratory Miscellatrcous Report, Las Alamos, New Mexico.

U.S. Department of Commerce, Apri] 1, 1991. New Mexico Population by Race and Ethricity 1990," Bureau of the Census, PL-94-171.

U.S. Department of Agriculture, 1992, "New Mcxico Agricultural Statistics, 1991," New Mexico Agricultural Statistics Service, Las Cnuces, New Mexico.

U.S. Department of Agriculure, 1991, "New Mexico Agricultural Statistics, 1990," New Mexico Africultural Statistics Service, Las Cruces, Now Mexico.

U.S. Deparment of Commerce, July 1991, "Benchurark Input-Output Accounts for the U.S. Econony, 1992," Survey of Current Business, Washington, D.C.

U.S. Department of Commerce, 1986. "County Business Patterns of 1984, New Mexico," Bureau of the Census, CBP-84.33.

U.S. Department of Agriculture, 1992. "Agricultural Statistics 1991,“ U.S. Government Printing Office, Washington D.C. 
APPENDIX 
Table 9. LANL North-Central New Mexico I/O Model Direct Coefficients, FY 1995.

\begin{tabular}{|c|c|}
\hline Spelor & $\begin{array}{c}\text { Direct } \\
\text { Coelitictents }\end{array}$ \\
\hline 1. Livestack \& Livestock Producte & 0.000000 \\
\hline 2. Other Agricultural Producte & 0.000000 \\
\hline 3. Forestry \& Fishery Products & 0.000000 \\
\hline 4. Agric, Foreatry \& Flahery Services & 0.000000 \\
\hline 5. Mining, Crude Petroleum \& Natural Gas & 0.000161 \\
\hline 6. Constrution & 0.003026 \\
\hline 7. Ordnsance \& Choinicel Manufacturing & 0,000027 \\
\hline 8. Food \& Kindred Products Manufiecturing & 0.000002 \\
\hline 9. Textiles Producls a Apperel Menufacturing & 0.000404 \\
\hline to. Lumber \& Wood Products Menufacturing & 0.000026 \\
\hline 19. Paper \& Publishing Manufacturing & 0,000041 \\
\hline 12, Peirclaum Refining \& Products Manufacturing & 0,000000 \\
\hline 13. Glass, Stone \& Clay Products Manufacturing & 0.000087 \\
\hline 14. Primary \& Fabricated Motals Manufacluring & 0.000702 \\
\hline 15. Computer, Office \& Service Equipment Menufacluring & 0.000000 \\
\hline 16. Elocirical Equipment Menufecturing & 0.004274 \\
\hline 17. Scientiflc Inatruments Manufacturing & 0,000928 \\
\hline 18. All Other Manufacturing & 0.001568 \\
\hline 19. Molor Freight Transportation \& Warehousing & 0.000058 \\
\hline 20. Att Other Transporlation & 0.000148 \\
\hline 21. Communication & 0.001279 \\
\hline 22. Elociric \& Gas UtIrities & 0,003600 \\
\hline 23. Water \& Other Utitties & 0.000022 \\
\hline 24. Wholosale Trade & 0,014849 \\
\hline 25. Rotall Trade & 0.010808 \\
\hline 26. Finance, Insurance \& Roal Estale & 0.001437 \\
\hline 27. Hotel Restatrant \& Othet Personal Services & 0,000368 \\
\hline 28. Data Processing \& Computer Services & 0,004181 \\
\hline 29. Manggement \& Consulting Services & 0.004004 \\
\hline 30. Engineering, Architecture $\Delta$ Surveying Services & 0.019639 \\
\hline 31. Other Buslness Servlces & 0.023771 \\
\hline 32. Automoblle \& Other Repair Services & 0,002233 \\
\hline 33. Amusement, Recrealton \& VIdeo Services & 0.000002 \\
\hline 34. Health, Educetion \& Social Services & 0.003560 \\
\hline 35. Government Services & 0.003974 \\
\hline 36. Local Government & 0.00207 \\
\hline 37. State Government & 0,003251 \\
\hline 38. LANL & 0.000000 \\
\hline 39. Househalds & 0.483268 \\
\hline Total New Mexico Expenditures & 0.594248 \\
\hline Totol Operating and Capltal Budget & 1.000000 \\
\hline
\end{tabular}

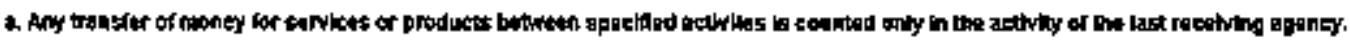


Table 10. LANL Stale-wide 1/O Model Direct Coefficients, FY 1995.

Direct

Sector

Coeffikients

1. Livastock \& Livastock Products

0.000000

2. Other Agricullural Products

0.000000

3. Forestry \& Fishery Products

0.000000

4. Agrle., Forestry \& Fithery Services

0.000004

5. Mining, Crude Petroleum \& Natural Gas

0.001102

6. Construction

0.006046

7. Ordnance \& Chemlcal Manufacturing

0.000050

a. Food \& Kindred Products Manutacturing

0.000042

9. Textlles Froducts \& Apparel Manufacturng

0.000021

10. Lumber \& Wood Products Manufacturing

0.000229

11. Paper \& Publishing Manufacturing

0.000235

12. Petroleum Retining \& Products Manutacturing

0.000001

19. Gless, Stone \& Clay Products Manufacturing

0.000104

14. Prinary \& Fabricated Metals Manufacturing

0.002246

15. Computer, Offica \& Service Equlpment Manufacturing

0.000000

16. Electrical Equlpment Manufacturing

0.004763

17. Scientific Instruments Manufacturing

0.001076

19. All Other Manufacturing

0.002128

19. Motor Freight Transportation Warehousing

0.000066

20. All Other Transportation

0.000416

21. Communication

0.001929

22. Elactric \& Gas Utilities

0.014108

23. Weter 8 Other Utilittes

0.000032

24. Wholesale Trade

0.042925

25. Rétall Trade

0.047414

26. Firance, Insurance \& Real Estate

0.001437

27. Hotel Restaurant \& Other Parsonal Services

0.000436

26. Data Processing \& Computer \$ervices

0.010185

29. Management \& Consulting Services

0.011275

30. Engineering, Arohiltecture \& Surveying Services

0.023648

31. Other Business Services

0.030903

32. Automoblle \& Other Repair Servlces

0.002779

33. Amusement, Recreation \& Video Services

0.000008

34. Health, Education \& Sacial Services

0.005968

35. Government Services

0.006110

3B. Local Govemment

0.002419

37. State Govemment

0.004044

38. LANL.

0.000000

39. Households

0.513647

Total New Maxioo Expenditures

0.738695

Total Operating and Capital Budget

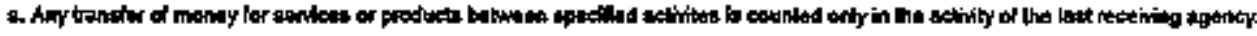


Table 11. Los Alamos National Laboratory, Central New Mexico, FY 1995, Indilrect Volume Employment Impacts by Subsector.

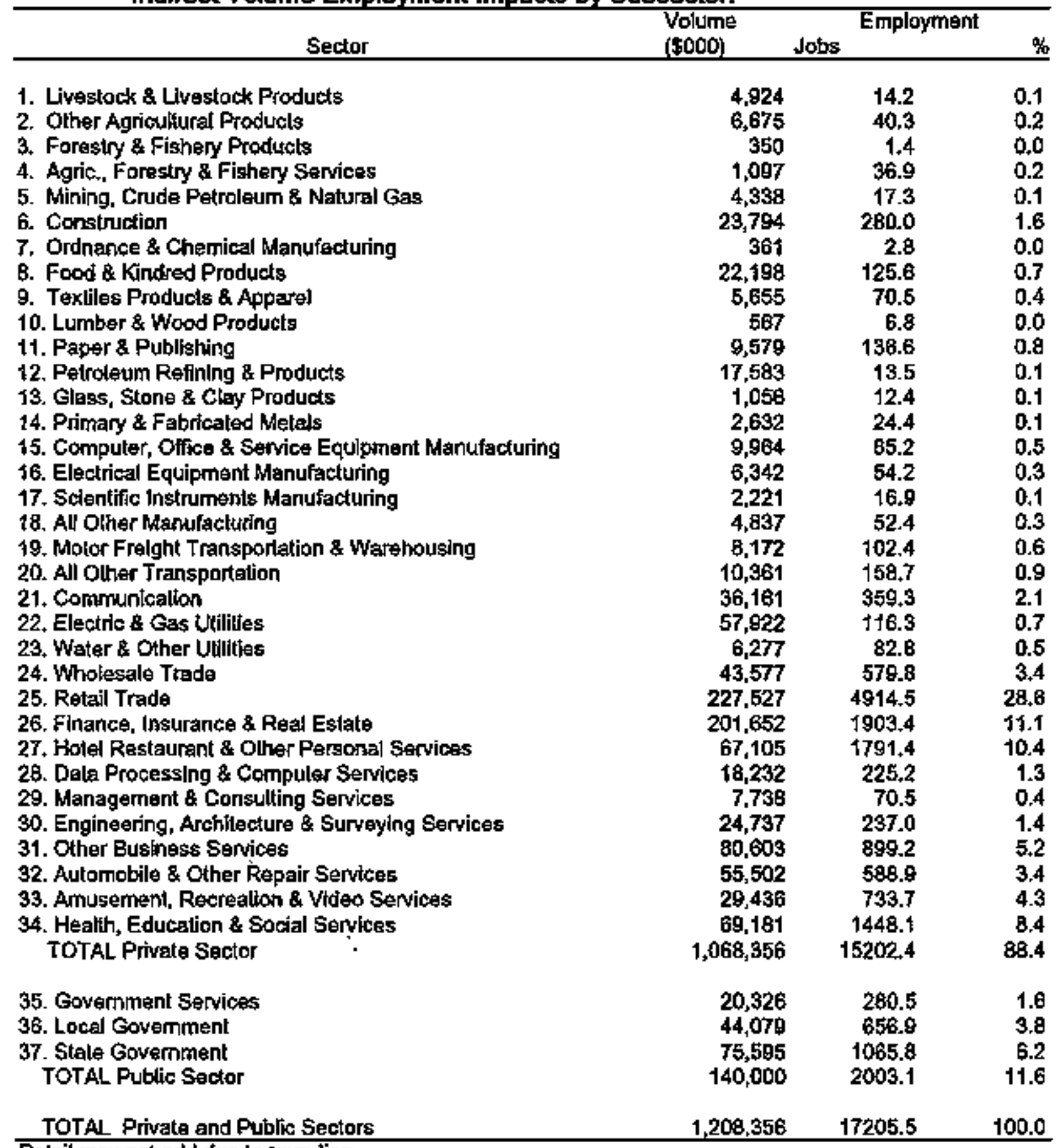

Delail may not add due lo rousubing. 
Table 12. Los Alamos National Laboratory, State of New Mexico, FY 1995, Indirect Volume Employment Impacts by Subsector.

\begin{tabular}{|c|c|c|c|}
\hline Seclor & $\begin{array}{l}\text { Volume } \\
(s 000)\end{array}$ & Jobs & $\begin{array}{r}\text { Emptoyment } \\
\%\end{array}$ \\
\hline 1. Livestock \& Livestock Products & 8,127 & 23.4 & 0.1 \\
\hline 2. Other Agricultural Products & 8,950 & 54.0 & 0.2 \\
\hline 3. Forestry \& Fishery Products & 448 & 1.8 & 0,0 \\
\hline 4. Agrlc., Forestly \& Fishery Services & 2,427 & 81.5 & 0.3 \\
\hline 5. Mining. Crude Patroleum \& Natural Gas & 33,706 & 134.3 & 0.6 \\
\hline 6. Construclion & 33,999 & 400.0 & 1.7 \\
\hline 7. Ordnance \& Chemical Manufacturing & 2,857 & 20.4 & 0.1 \\
\hline 8. Food \& Kindred Producls & 34,250 & 193.8 & 0.8 \\
\hline 9. Textiles Products \& Apparel & 5,680 & 73,3 & 0.3 \\
\hline 10. Lumber Wood Producls & BBO & 10.6 & 0.0 \\
\hline 11. Paper \& Publlshing & 8,654 & 123.4 & 0.5 \\
\hline 12, Pelroleum Refining \& Products & 31,177 & 23.9 & 0.1 \\
\hline 13. Glass, Stone \& Clay Products & 2,139 & 25.1 & 0.1 \\
\hline 14. Primary \& Fabricated hetals & 6,975 & 64.5 & 0.3 \\
\hline 15. Compuler, Olfice \& Servce Equjpinent Manufacturing & 12,060 & 103.1 & 0.4 \\
\hline 16. Electrical Equjgment Marsufacturing & 12,146 & 103.9 & 0.4 \\
\hline 17. Scientific Instruments Manufacturing & 2,515 & 19.1 & 0.1 \\
\hline 18. Alt Other Manufacluring & 8,419 & 91.2 & 0.4 \\
\hline 19. Motor Frelght Transportalion \& Warehousing & 12,012 & 150,5 & 0.6 \\
\hline 20. All Other Transportalion & 20,939 & 320.7 & 1.4 \\
\hline 21. Communication & 39,408 & 391.6 & 1.7 \\
\hline 22. Electric \& Gas Utilities & 88,132 & 176.9 & 0.8 \\
\hline 23. Water \& Other Utilitiss & $\mathbf{7 , 7 2 0}$ & 101.8 & 0.4 \\
\hline 24. Wholestale Trade & 100,513 & 1337.3 & 5.7 \\
\hline 25. Retail Trade & 315,265 & 6809.6 & 29.1 \\
\hline 26. Finance, Insurance \& Real Estate & 250,422 & 2363.7 & 10,1 \\
\hline 23. Hotel Restaurant \& Olher Personal Services & 93,729 & 2502.2 & 10.7 \\
\hline 28. Data Processing \& Computer Services & 24,651 & 304,5 & 1.3 \\
\hline 29. Management \& Consulting Services & $\mathbf{2 7}, \mathbf{5 3 0}$ & 251.0 & 1.1 \\
\hline 30. Engineering, Archittecture \& Survaying Services & 29,858 & 286.0 & 1.2 \\
\hline 31. Other Business Services & 90,339 & 1007.8 & 4.3 \\
\hline 32. Aulomobile \& Other Repair Services & 68,483 & 726.7 & 3.1 \\
\hline 33. Amusement, Recreation \& Vdea Services & 34,358 & 856.4 & 3.7 \\
\hline 34. Health, Educztion \& Social Services & 84,901 & 1777.1 & 7.6 \\
\hline TOTAL Pivate Sector & 1503669 & 20911.2 & 89.2 \\
\hline 35. Government Services & 25.877 & 357.1 & 1.5 \\
\hline 36. Local Govemment & 54,210 & $807+9$ & 3.4 \\
\hline 37. Slate Govemment & 96,771 & 1384.3 & 5.8 \\
\hline TOTAL Public Sector & 176859 & 2529.3 & 10.8 \\
\hline TOTAL Private and Public Seclors & $1,680,527$ & 23440.1 & 100.0 \\
\hline
\end{tabular}

Detail may nol add due to tounding. 